UDC 811.111

DOI https://doi.org/10.32838/2663-6069/2020.2-2/17

Ivasiuk N. $A$.

National University "Odessa Maritime Academy"

\title{
DYNAMIC ADAPTNESS OF NATIONAL ASPECTS FOR MARITIME ENGLISH TEACHING THROUGH UNIFIED COMMUNICATION PLATFORM
}

Specificity of computer-mediated teaching Maritime English (ME) as a professional subject in synchronous and asynchronous modes is connected with linguistics, neurolinguistics, pragmatic and social modelling of teacher-trainer and learner-trainee behavioral variability. Coming from teaching ME to foreign students we accumulated some practical experience and investigate how phonological, lexicogrammatical, discourse, social/communicative frameworks of teaching process "face-to-face" and "on-line" modes will contribute to creating local structures of sub-language of specialty. Other words, we mean to come from contextualized to decontextualized process of teaching ME, from coding to decoding the linguistic information. We've tried to approach this position getting ready the teaching material for United Communication Platform (UCP) within limits of case-marking system. This one in our opinion is to be construed coming from the event-argument structure in static meta-system to dynamic linguistic/developing system.

The effectiveness of this transition process can be defined positively when learners' languagel sublanguage acquisition will exceed the combination of their initial training state and the input.

National peculiarities of pronunciation to be adjusted and mitigated in converting to ME are only the top of the iceberg. We would like to trace agents or elements of ME emergent behavior leading to self-organization and interaction in ME properly structured ways.

Key words: behavioral, variability, framework, contextualized, case-marking, "event-argument", transition, input, emergent.

Introduction. We continue our research as for exploring possibilities, effectiveness, structuring and restructuring Unified Communicative Platform (UCP) for teaching-learning Maritime English (ME) by users in different countries, by seafarers, non-native speakers. To the main idea of efforts directed at developing UCP for seafarers our previous article was devoted. Just to clear out the trend of research we refer to one of its passages. Our idea is to create universal English Language communication platform, based on Cloud technologies, for seafarers all over the world targeted at non-native speakers, levels $\mathrm{A} 1-\mathrm{A} 2$ reaching $\mathrm{B} 1-\mathrm{B} 2$. The high value of any educational process is based on its cognitive load and creation of cognitive learning environment. We will try to unite the technical possibilities of unified communication platform with its educational advantages. "Face-to-face" element communication in virtual laboratory, "utterance-to-text" based tools, voice-based applications, video-based services, web conferencing platform, real-time presence in collaboration platform or "virtual teacher" presence will be good in conglomeration with methodology of minimalistic theory of language acquisition and accelerated learning of foreign languages (ALFL) and learning modalities [1]. We devote this article to the aspects of its functioning from the point of view of static and dynamic worlds of complex systems, in particular applied linguistics.

Before, we analyzed the existing functioning platforms for teaching and testing ME: MARLINS Test Platform, Sea Talk, MARTEL Plus, MARTEL- Maritime Tests of English language, Captains - Maritime Training. They are effective, which fact can be defined by scoring results, their specialty-based purposefulness. Their resources are multiple-lexical, grammatical, phonological, vocabulary with potential of modelling to some extent, learners' behavior. Coming from researches of adherents of presenting "learning medium-world" as complex systems [3, p. 305-352; 5, p. 128-147] we would like to construe such a dynamic complexity of ME teaching world of specialty which would be not only of segmental, fractional nature but combined as "entity", like professional behavioral emergent. The framework of it should be flexible, of linear and non-linear character, consisting of such agents or elements, which can change and adapt in response to learners' feedback and interact in structured ways.

Those we are speaking about, in our mind, can provide quick dynamic adaptness to ME teach- 
ing through UCP by non-native speakers/learners. Every student/perceiver of teaching information in the subject/here ME while being taught should feel and perceive himself/herself within this complex system/“entity" or corporate body of language/sublanguage of specialty. It is especially important for learners, introverts by their psychological type. This type of learners is very sensitive and effected by disfluencies and ungrammaticality stemming from the demands of on-line processing [2, p. 229-233]. When working with students, non-native speakers of different nationalities, European and more Asian/ learners, you should remember the following. The overall or periodic change in structuring ME teaching process not always proceed at uniform rate among speakers/possible speakers of language. But we as ME teachers in different modes of teaching can motivate our recipients creating applied linguistic concerns.

Mechanisms of adapting dynamically nonnative speakers, learners of $\mathrm{ME}$ in on-line and autonomous modes through UCP. Many questions arise from investigating these mechanisms. Complexity of language system/systems in general was investigated by many famous scientists in the world $[4$, p. $23-25 ; 10$, p. $213-226]$, including peculiarities of dynamic mechanisms of teaching-learning EL by non-native speakers.

The approach we have forwarded in the article is not investigated widely but it's of international importance. We know that almost $90 \%$ of world transportations are realized by shipping industry. Our own quantitative analysis of reasons of marine accidents has led us to the conclusion (and it has been supported by world statistics and international conventional documents) to the following fact. About $16 \%$ of marine accidents happen because of lack of communication and misunderstanding through lack of EL practical communicative skills.

Every researcher in linguistics can try to program learner's implicit claim about dynamics in teaching learning process as formation of his speech, interpretation of the information heard and amplification of his communicative skills of response. This process can be evaluated as three-place relation process. And to make it more traceable for investigator it is necessary to set up a relatively stable learner's state for his transition period from one native language to another (i. e. ME). Signposts in this process should be - point of transition $\rightarrow$ phase transition $\rightarrow$ leading to increased behavioral variability methodology.

Methodology. To establish the guideline, close interlink of these 3 positions to control and monitor them the teacher/tutor in the classroom or in the stu- dio should be aware of importance of cognition how learners think, conceptualize and how to initiate transforming their thinking into speaking, listening and writing.

We agree absolutely with the affirmation [7, p. 118] that general cognitive capacities enable humans, in our case we imply teacher $\rightarrow$ learner:

- to establish joint attention;

- to understand the communicative intentions of others;

- to form categories;

- to detect patterns, to imitate;

- to notice new fluctuations into communicative massif.

These cognitive capacities of humans will be effectively realized, in our opinion, if language/ sublanguage system will be organized in horizontal and vertical dimensions integrated. Static meta-system as a part of complex system first should be used to place the learner inside the specific context horizontally where benchmarks are the popularized thematic words consistent with learners' intentions. Minimal set of core thematic words forming a string of interrupted theme-rhemes will give the linguistic nativist possibility to overcome retardation in adaptability to linguistic progress from his initial language acquisition state to the expected input $[8 ; 9]$.

Meta learning at the first stage of learning process itself (i.e. devoted to ME teaching $\rightarrow$ learning) will be facilitated by the teacher/tutor's efforts to decoding specific terminological information by decontextualizing it. And this process will involve simplification in perceiving ME sub-specialty structures. It is especially valuable for non-native speakers, students/learners who has difficulties of phonological, grammatical character. Trainers/tutors who are aimed at such group of students in on-line and off-line processing, create preliminary "target domain" of the thematic topic. Being "embedded" into this domain as topical here and topics adjacent to it the learner will acquire minimal basic pattern of experience, which then will be semantically prototypical for future constructions with which they are associated. For example, we develop professional topic for navigators "Salvage" and at the first step give the horizontal minimal dimension of the topic in the following string (Scheme 1) with audio translation into native language [10, p. 213-226].

\section{Scheme 1}

$$
\begin{aligned}
& \quad \mathrm{N}_{1} \rightarrow \mathrm{N}_{2} \rightarrow \mathrm{N}_{3} \rightarrow \mathrm{N}_{4} \rightarrow \mathrm{N}_{5} \rightarrow \mathrm{N}_{6} \rightarrow \mathrm{N}_{7} \rightarrow \mathrm{N}_{8} \rightarrow \\
& \mathrm{N}_{9} \rightarrow \mathrm{N}_{10} \\
& \quad \mathrm{~V}_{1} \rightarrow \mathrm{V}_{2} \rightarrow \mathrm{V}_{3} \rightarrow \mathrm{V}_{4} \rightarrow \mathrm{V}_{5} \rightarrow \mathrm{V}_{6} \rightarrow \mathrm{V}_{7} \rightarrow \mathrm{V}_{8} \rightarrow \\
& \mathrm{V}_{9} \rightarrow \mathrm{V}_{10}
\end{aligned}
$$

Note: $\mathrm{N}$ - noun; $\mathrm{V}$ - verb 
The selection of this string is based on lexical regularity, as for the audio pronunciation by tutor or recorded in any mode processing, it should not be connected with possible sound change, easily leading to lexical diffusion. The learners of any nationality, especially with absolutely different phonology - rhythm, intonation, stress, may be gradually phonetically motivated by trainer/tutor in the studio or in classroom by polishing pronunciation of these key strings.

Another string of horizontal dimension of meta-learning system may be presented by meaningful collocations (Scheme 2).

\section{Scheme 2}

$\mathrm{N} \rightarrow \mathrm{N}$ - safety precautions;

$\mathrm{A} \rightarrow \mathrm{N}$ - minor/major damage;

$\mathrm{V} \rightarrow \mathrm{N}-$ to jettison cargo, to transfer cargo;

$\mathrm{P} \rightarrow \mathrm{N}$ - detailed records.

Note: $\mathrm{N}$ - noun; $\mathrm{V}$ - verb; $\mathrm{A}$ - adjective; $\mathrm{P}$ - pronoun

They repeat to some extent the string before, but at the same, new ones appear which are within the propositional attitude to the thematic environment. These collocations as from the first string should play the role of signposts $\rightarrow$ attractors, which will provide learners with minimal linguistic knowledge of the topic.
If the first and second strings are to be taught at the level of imitation, the next step should be of associative function, with more or less productive interpretation. The trainer/tutor should develop themerheme direction, giving interpretation of the key item. Examples:

1. A salvage operation is underway. (theme-topic)

2. Salvage was taken from a ship sunk in the river. (rheme-commitment of...)

We start transition phase from meta-learning with self-control, self-organization and self-regulation to emergentism as for linguistic behavioral variability. That is the high time for semantically prototypical constructions for this theme (Scheme 3).

Among these collocations - fixed, semi-fixed expressions, idioms - typical and frequently used expressions for this very topic.

The trainer's task will be of promotional attitude towards the learners in order to facilitate their code-switching from ME into native language and vice versa, to understand to what extent these patterns are clustering into meaningful utterances. Just next tasks to work out with learners, especially those whose native language has another, sometimes almost opposite word order in comparison with EL, are aimed at coming

Scheme 3

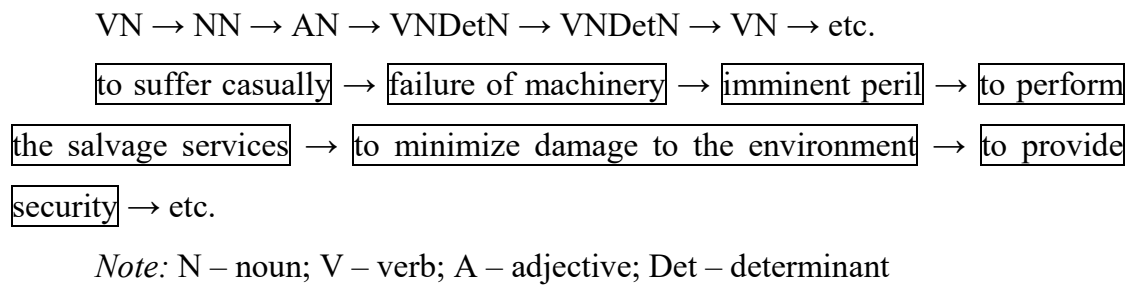

Det $\rightarrow$

$\mathrm{N} \rightarrow$

$\mathrm{VP} \rightarrow$

Prep $\rightarrow$

$\mathrm{N} \rightarrow$

$\leftarrow$ Conj

$\leftarrow$ SP

$\leftarrow$ Conj

$\leftarrow \mathrm{MP}$

$\leftarrow$ Pron

$\mathrm{N} \leftarrow$ Det

Note: Det - determinant; $\mathrm{N}$ - noun; $\mathrm{V}$ - verb; VP - verbal predicate; Prep - preposition; Conj - conjunction; Pron - pronoun; SP - subject predicate; MP - modal predicate

A vessel is considered in peril if she

is in danger or could become a

danger.

Scheme 4 
from point of transition to phase transition. We should adapt learners/non-native speakers to self-organization in applying ready-made patterns to transiting them to emergent linguistic behaviour.

So, a string/a set of words-parts of speech given at random is proposed to the learners to rearrange to express event-argument structure. Example:

1. In, peril, is considered, could, become, a, vessel, if, is, it, in, in, danger, or, danger.

The task of a trainer is to inspire learners to restructure smoothly the proposed set of words following the scheme (Scheme 4).

Another way of creating cohesion and coherence, maintaining them in discourse is to moderate learners' decisions by restoring the contextual fractals, like: Complete the sentences, or Give the beginning of the sentences.

But these tasks can be performed only after "embedding" the learner into the context as a core of the whole topic and presented as a number of texts, extending successively and reflecting thematic vocabulary. The tutor works out this vocabulary with students in various kinds of activities, or as it is so-called, populate the words and word combinations with students' future intentions. And then such a linguistic tendency as emergentism proposes, structured inventory of symbolic units which act as form-meaning composites [6, p. 61-82]. They are not exactly fixed and semi-fixed expressions, idioms and frozen collocations but perform the function of main contextual attractors of the topic, i.e. for salvage operations from the first text of the module (Appendix 1) they may be "put passenger ship safely back to", "to carry passengers", "successfully evacuated", "left on board", "to take the life-boats", etc. The same structured inventory may be repeated with other texts of the thematic topic. That, as we consider, will be like conceptualizing thinking for speaking, coming from phase transition to behavioural variability. The tutor will try to model the minimal patterns of linguis- tic behaviour which may have vertical dimensional markers. These markers may be connected with the learners' emergency in developing their language resources like their argumental ability to express possible conditions of the described actions, their modality, dialogical interaction with the increased degree of complexity and at last reinforcement or entrenchment in the way of linguistic commitment or performance: trainee $\rightarrow$ trainee $\rightarrow$ tutor $\rightarrow$ trainee $\rightarrow$..

Any combination in collaboration with tutor and other participants of virtual or classroom laboratory with creating realistic formula of possible professional ME applications will show us the progress in the educational process.

\section{Text 1}

The grounding, in early December 2009, of empty Antarpply Expeditions' cruise ship Ushuaia off the Antarctic coast put passenger ship safety back on the maritime new agenda. The vessel, which was carrying 89 passengers, was successfully evacuated by the Chilean Navy and remained afloat with 33 crew members left on board to carry out salvage operations. However, the accident came little more than a year after another cruise vessel, explorer, sank in the region, forcing its 154 occupants to take to the lifeboats. Cruising on the Antarctic poses unique demands in terms of vessel construction, equipment and safety arrangements. Now, more than ever, effective safety solutions remain crucial to the continued health of the industry.

Conclusions. We tried to investigate the possibility how to create dynamic framework of communication platform. We consider it is rather complicated process and needs the convertible code of studied language with taking into account fluctuations from subcode of native sublanguage of specialty to sub-code of ME. The tutor will be successive in his efforts if acting in compliance with all the current progressing changes, which this code is undergoing.

\section{References:}

1. Ivasiuk N., Shapo V. Unified English Language Communication Platform. The New Wave of Excellence in Maritime Education and Training: The $1^{\text {st }}$ IMLA-IMEC-ICERS Conference, Philippines, 22-25 October, 2018. P. 1-9.

2. Larsen-Freeman D., Cameron L. Complex Systems and Applied Linguistics. Oxford : Oxford University Press, 2009. 287 p.

3. Ellis N. At the interface: Dynamic interactions of explicit and implicit language knowledge. Studies in Second Language Acquisition. 2005. Vol. 27. Iss. 2. P. 305-352.

4. Ellis N. Dynamic systems and SLA: The wood and the trees. Bilingualism: Language and Cognition. 2007. Vol. 10. Iss. 1. P. 23-25.

5. Evans J. The emergence of language: a dynamic systems account. Handbook of language development / E. Hoff, M. Shats (eds.). Malden, MA : Blackwell, 2007. P. 128-147.

6. Tomasello M. First steps toward a usage-based theory of language acquisition. Cognitive Linguistics. 2000. № 11. P. 61-82. 
7. Tomasello M. Constructing a Language: A Usage-based Theory of Language Acquisition. Cambridge, MA : Harvard University Press, 2003. 388 p.

8. Diessel H. Linguistic nativism. URL: http://www.personal.uni-jena.de/ x4diho/LA_Linguistic_nativism.pdf.

9. Chomsky N. Three Factors in Language Design. Unpublished manuscript.

10. Chomsky N. The Minimalist Program. Cambridge, MA : MIT Press, 1995. 420 p.

\section{ІвасюК Н. О. ДИНАМІЧНА АДАПТИВНІСТЬ НАЦІОНАЛЬНИХ}

\section{АСПЕКТІВ ВИКЛАДАННЯ МОРСЬКОЇ АНГЛІЙСЬКОЇ МОВИ ЗАВДЯКИ УНІФІКОВАНІЙ КОМУНІКАЦІЙНІЙ ПЛАТФОРМІ}

Специфіка комп'ютерного викладання морської англійської мови як професійного предмета в синхронному й асинхронному режимах пов'язана з лінгвістикою, нейролінгвістикою, прагматичним і сочіальним моделюванням поведінкової мінливості викладача та того, хто навчається. 3 огляду на досвід викладання морської англійської мови іноземним студентам ми накопичили певний практичний досвід та розглянули питання про те, як фонологічний, лексико-граматичний, мовний, соціальний/ комунікативний каркас навчального процесу типу «обличчя до обличчя» та «онлайн» сприятимуть створенню локальних структур підмови у спеціальності. Інакше кажучи, ми маємо на увазі перехід від контекстуалізації до деконтекстуалізаиї процесу викладання морської англійської мови, від кодування до декодування лінгвістичної інформачії. Ми намагалися підійти до иьього положення y процесі підготовки навчального матеріалу для уніфікованої комунікаційної платформи в межах системи предметного навчання. На нашу думку, вона повинна бути створена з огляду на структуру «аргумент - події» у статичній метасистемі щодо динамічної лінгвістичної/розвиваючої системи.

Ефективність изього перехідного процесу може бути визначена позитивно, коли мовні/nідмовні здобутки того, хто навчається, перевищуватимуть об'єднання його початкової підготовки та набутого рівня.

Начіональні особливості вимови, які необхідно скорегувати та пом'якшити під час переходу на морську англійську мову, - ие тільки верхівка айсбергу. Ми прагнемо відстежити агенти або елементи діяльнісної поведінки того, хто навчається, у межсах морської англійської мови, що приводить до самоорганізачії і взаємодї його з викладачем завдяки чітко структурованим засобам подачі навчального матеріалу.

Ключові слова: поведінка, мінливість, каркас, контекстуалізачія, предметне навчання, «аргумент подї̈,, перехідний період, подання інформаиії, діяльнісний підхід. 